\title{
Efek samping terapi radiasi penderita kanker kepala dan leher pada kelenjar saliva
}

\author{
Barunawaty Yunus \\ Bagian Radiologi \\ Fakultas Kedokteran Gigi Universitas Hasanuddin \\ Makassar, Indonesia
}

\begin{abstract}
Nasopharyngeal cancer has different malignancy types, based on its location. The most frequent type of nasopharyngeal cancer is carcinoma of squamous cell which happens on cells inside nose, mouth, and throat. The rare types happened such as salivary gland tumor, lymphoma, and sarcoma. There are three main therapies to treat nasopharyngeal cancer; they are radiation therapy, surgery, and chemotherapy. The main treatment is radiation therapy or surgery and chemotherapy or combination both of them. Chemotherapy is often conducted as an additional treatment. Combination treatment between those three treatments optimally can be used for nasopharyngeal cancer patient based on the location and disease stadium. Radiation therapy on nasopharyngeal cancer can caused some side effects, such as mucositis, salivary gland dysfunction, taste sense dysfunction and malnutrition, tooth disorders, bone transforming, cutaneous transforming, nerve disorders, decreasing of intellectual, lost of hearing sense, complication of malignant cancer caused by radiation, and intracranial bleeding.
\end{abstract}

Key word: Radiation therapy, salivary gland, neck and head cancer.

\begin{abstract}
ABSTRAK
Kanker kepala dan leher mempunyai jenis keganasan yang berbeda, tergantung lokasi terjadinya. Jenis kanker kepala dan leher yang paling umum terjadi adalah karsinoma sel squamous yang terjadi pada sel di dalam hidung, mulut dan tenggorokan. Jenis yang sedikit terjadi, antara lain tumor kelenjar saliva, limpoma dan sarkoma. Ada tiga jenis terapi utama untuk menangani kanker kepala dan leher, yaitu terapi radiasi, pembedahan dan kemoterapi. Perawatan yang utama adalah terapi radiasi atau pembedahan dan kemoterapi atau kombinasi keduanya. Kemoterapi sering dilakukan sebagai perawatan tambahan. Perawatan kombinasi ketiga cara di atas secara optimal dapat digunakan untuk pasien kanker kepala dan leher tergantung lokasi terjadinya dan stadium penyakit. Terapi radiasi pada kepala dan leher dapat menyebabkan beberapa efek samping seperti mukositis, disfungsi kelenjar saliva, disfungsi indera pengecap dan malnutrisi, gangguan gigi geligi, perubahan pada tulang, berubahan kutaneus, kerusakan saraf, penurunan intelektual, hilangnya pendengaran, terjadinya kanker ganas akibat radiasi dan perdarahan otak.
\end{abstract}

Kata kunci: Terapi radiasi, kelenjar saliva, kanker kepala dan leher.

Koresponden: Barunawaty Yunus, J1. Sunu M 17, Makassar, Indonesia. E-mail: barunawaty@yahoo.com. 


\section{PENDAHULUAN}

Kanker kepala dan leher mempunyai jenis keganasan yang berbeda, tergantung lokasi terjadinya (tumor primer). Contohnya, kanker pada pita suara yang sangat berbeda dengan yang terjadi pada hipopharinx yang jaraknya hanya beberapa inci dari pita suara.

Jenis kanker kepala dan leher yang paling umum terjadi adalah karsinoma sel squamous yang terjadi pada sel di dalam hidung, mulut dan tenggorokan. Jenis yang sedikit terjadi antara lain tumor kelenjar saliva, limpoma, dan sarkoma. ${ }^{1}$

Ada tiga jenis terapi utama untuk menangani kanker kepala dan leher yaitu terapi radiasi, pembedahan dan kemoterapi. Perawatan yang utama adalah terapi radiasi atau pembedahan dan kemoterapi atau kombinasi keduanya. Kemoterapi sering sebagai perawatan tambahan. Perawatan kombinasi ketiga cara di atas secara optimal dapat digunakan untuk pasien kanker kepala dan leher tergantung lokasi terjadinya dan stadium penyakit. ${ }^{1}$

Seperti terapi lainnya, terapi radiasi memiliki efek samping terutama pada anak. Hal ini tergantung pada umur, lokasi penyinaran, luas lapangan penyinaran, organ vital di sekitar tumor, metode dan alat radiasi yang dipergunakan, serta jumlah dosis yang diberikan. Efek sampig yang muncul bisa segera terjadi bisa juga lambat, dapat terjadi secara lokal maupun umum, dan dapat terjadi dari yang ringan sampai berat. ${ }^{2}$

Terapi radiasi pada kepala dan leher dapat menyebabkan beberapa efek samping seperti mukositis, disfungsi kelenjar saliva, disfungsi indera pengecap dan malnutrisi, gangguan gigi geligi, perubahan pada tulang, berubahan kutaneus, kerusakan saraf, penurunan intelektual, hilangnya pendengaran, terjadinya kanker ganas akibat radiasi dan perdarahan otak. ${ }^{2}$
Yang akan dibahas pada karya ilmiah ini adalah efek samping terapi radiasi penderita kanker kepala dan leher pada kelenjar saliva.

\section{TINJAUAN PUSTAKA}

Saliva adalah suatu cairan mulut yang kompleks, tidak berwarna, yang disekresikan dari kelenjar saliva mayor dan minor untuk mempertahankan homeostasis dalam rongga mulut. ${ }^{3}$ Pada orang dewasa yang sehat, diproduksi saliva lebih kurang 1,5 liter dalam waktu 24 jam. Sekresi saliva dikendalikan oleh sistem persarafan, terutama sekali oleh reseptor kolinergik. Rangsang utama untuk peningkatan sekresi saliva adalah melalui rangsang mekanik. ${ }^{4}$

Saliva mempunyai beberapa fungsi penting di dalam rongga mulut, diantaranya sebagai pelumas, aksi pembersihan, pelarutan, pengunyahan dan penelanan makanan, proses bicara, sistem buffer dan yang paling penting adalah fungsi sebagai pelindung dalam melawan karies gigi. ${ }^{3,4}$ Kelenjar saliva dan saliva juga merupakan bagian dari sistem imun mukosa. Sel-sel plasma dalam kelenjar saliva menghasilkan antibodi, terutama sekali dari kelas Imunoglobulin A (Ig A), yang ditransportasikan ke dalam saliva. Selain itu, beberapa jenis enzim antimikrobial terkandung dalam saliva seperti lisozim, laktoferin dan peroksidase. $^{3}$

Saliva adalah hasil dari berbagai kelenjar saliva yang terletak di bawah mukosa mulut. Setiap hari, kelenjar saliva manusia menghasilkan hampir $600 \mathrm{ml}$ saliva serous dan mucin yang mengandung mineral, elektrolit, buffer, enzim dan inhibitor enzim, faktor pertumbuhan, sitokin, immunoglobulin, seperti immunoglobulin sekretori A (sIgA), mucin dan glikoprotein lainnya. Protein yang ditemukan dalam saliva, seperti laktoferin, lisozim, peroksidase, defensin dan histatin, dapat merusak atau menghambat 
pertumbuhan mikroorganisme dalam rongga mulut; misalnya, histatin yang memiliki sifat fungsidal. ${ }^{4}$

\section{ETIOLOGI}

Terapi radiasi pada daerah leher dan kepala untuk perawatan kanker telah terbukti dapat mengakibatkan rusaknya struktur kelenjar saliva dengan berbagai derajat kerusakan pada kelenjar saliva yang terkena terapi radiasi. Hal ini ditunjukkan dengan berkurangnya volume saliva. Jumlah dan keparahan kerusakan jaringan kelenjar saliva tergantung pada dosis dan lamanya penyinaran. $^{3}$

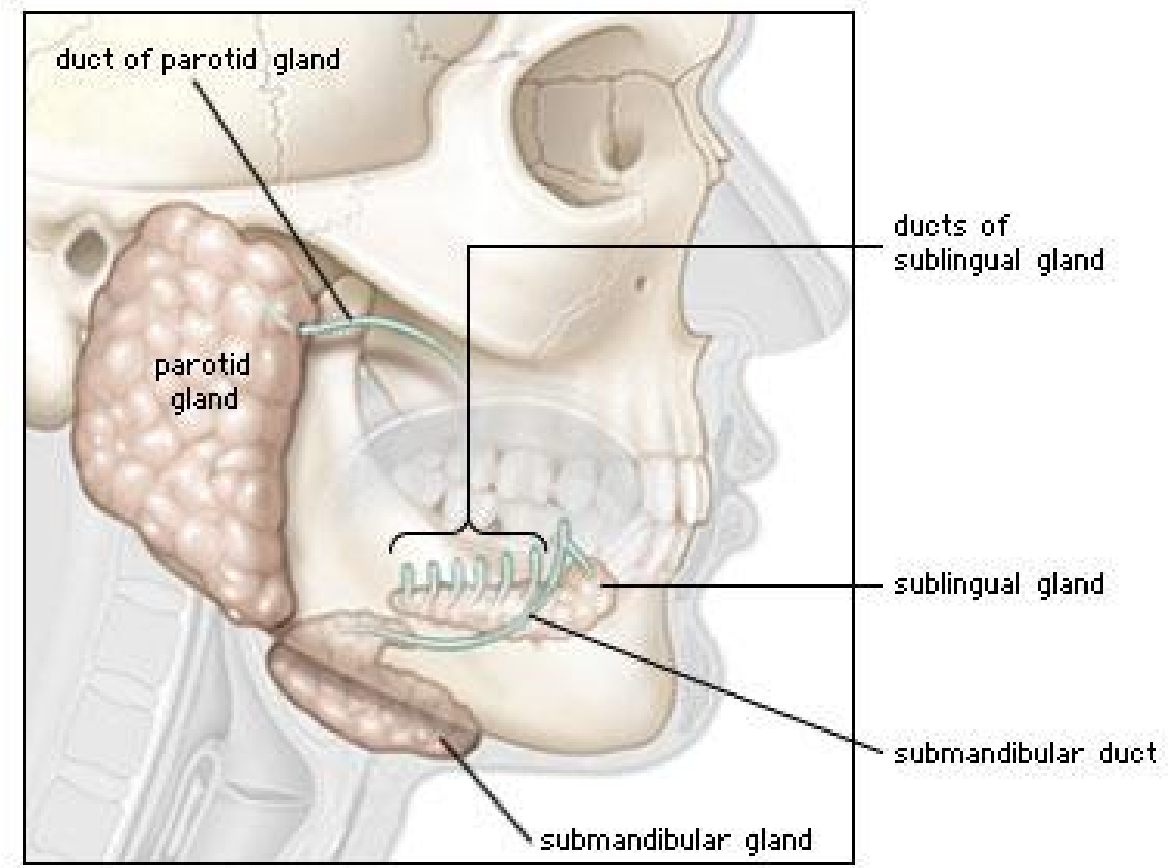

Gambar 1. Gambaran anatomis dari galndula salivarius

Tabel 1. Hubungan antara dosis penyinaran dan sekresi saliva (Sumber: Hasibuan Sayuti. Keluhan mulut kering ditinjau dari faktor penyebab, manifestasi dan penanggulangannya. Available from: http://library.usu.ac.id . Diakses: 5 Maret 2007

\begin{tabular}{cl}
\hline Dosis & \multicolumn{1}{c}{ Gejala } \\
\hline$<10$ Gray & Reduksi tidak tetap sekresi saliva \\
$10-15$ Gray & Hiposialia yang jelas dapat ditunjukkan \\
$15-40$ Gray & Reduksi masih terus berlangsung, reversibel \\
$>40$ Gray & Perusakan irreversibel jaringan kelenjar (Hiposialia irreversible). \\
\hline
\end{tabular}




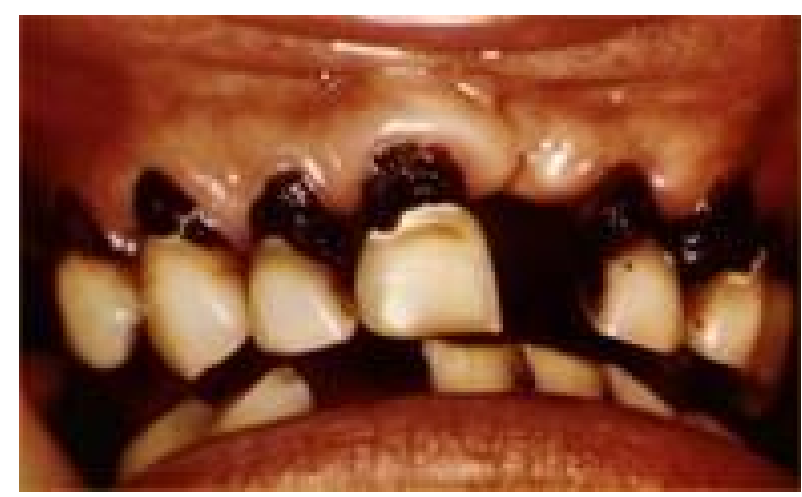

Gambar 2. Xrostomia akibat radiasi (Sumber: Gupta A, Joel BE, Herve S. Hyposalivation in elderly patients. $\mathbf{J}$ Can Dent Assoc 2006; 72(9):841-6). ${ }^{7}$

Glandula saliva mayor harus dihindari terkena radiasi dengan pancaran sinar 20 sampai 30 Gy selama radioterapi untuk kanker mulut atau oropharink. Komponen parenkim lebih radiosensitif (glandula parotid lebih jika dibandingkan glandula submandibular atau sublingual). Gejala kehilangan sekresi saliva setelah beberapa minggu pertama radioterapi baru biasanya dapat terlihat. Pengurangan aliran saliva tergantung dari dosis yang diberikan, biasanya pada 0-60 Gy. Mulut akan menjadi kering (xerostomia) dan sakit, serta pembengkakan dan nyeri karena berkurangnya saliva menyebabkan kehilangan fungsi lubrikasi. ${ }^{4}$

\section{Patofisiologi}

Selama radiasi, sekresi kelenjar biasanya berkurang, tebal, lengket, dan sangat mengganggu pasien. Beberapa pasien tidak dapat memproduksi lebih dari $1 \mathrm{ml}$ (15 tetes) cadangan saliva dalam waktu 10 menit. Durasi ini menurunkan fungsi air liur yang bermacam-macam antara satu pasien dengan pasien yang lain. Beberapa regenerasi dapat terjadi selama beberapa bulan setelah pengobatan, serta tanda dan gejala dari serostomia dapat diubah. Tanda dan gejala dari serostomia adalah mulut kering dengan perasaan tidak nyaman, sukar berbicara dan menelan meskipun demikian, proses mengembalikan saliva sampai cukup untuk kenyamanan dan fungsi mulut membutuhkan waktu sampai 12 bulan. Selain itu, sisa saliva yang tidak mencukupi merupakan sebagian besar keluhan utama setelah pengobatan. Bila kelenjar parotis terkena sinar radiasi pada saat pengobatan, pengurangan saliva adalah dampak utamanya, dan prognosis untuk pengobatan selanjutnya sangat buruk. Kenyataannya, semakin tinggi dosis radiasi, semakin buruk prognosis serostomia. Derajat kerusakan kelenjar saliva bergantung pada jumlah kelenjar saliva yang terpapar radiasi dan dosisnya. Permulaan dosis radiasi yang berkisar 23 dan 25 Gy, merupakan ambang destruksi permanen kelenjar saliva., ${ }^{5,6}$

Gambaran histologi dari respon jaringan yang mengalami inflamasi akan muncul segera setelah terapi radiasi, khususnya pada serous acini (kelenjar serous). Beberapa bulan setelah radioterapi dilakukan, inflamasi akan semakin kronik dan glandula akan menjadi fibrosis, adiposis, kehilangan pembuluh darah, dan seiring dengan itu jaringan parenkim akan mengalami degenerasi. Hal tersebut akan menimbulkan serostomia. $^{5}$

Perubahan saliva akan berpengaruh terhadap mikroflora mulut dan gigi. Hal tersebut sering memicu terjadinya karies oleh karena radiasi. Setelah radiasi glandula saliva mayor, mikroflora akan berubah, dan perubahan tersebut dapat menyebabkan saliva menjadi asam dan menimbulkan plak. Pasien yang menjalani radioterapi akan menyebabkan peningkatan Streptococcus mutans, Lactobasilus, dan Candida. Karena jumlah saliva yang sedikit, kental, dan asam beberapa pasien akan mengalami karies radiasi. $^{5}$ 


\section{PEMBAHASAN}

Tingkat perubahan kelenjar saliva setelah radiasi ada beberapa tahap, yaitu untuk beberapa hari, terjadi radang kelenjar saliva. Setelah satu minggu terjadi penyusutan parenkim sehingga terjadi pengecilan kelenjar saliva dan penyumbatan. Selain berkurangnya volume saliva, juga terjadi perubahan lainnya pada saliva, yaitu viskositas menjadi lebih kental dan lengket, $\mathrm{pH}$ menurun dan sekresi IgA berkurang. Waktu yang diperlukan untuk mengembalikan kecepatan sekresi saliva menjadi normal kembali tergantung pada individu dan dosis radiasi yang telah diterima. ${ }^{3}$

Minum air dan berkumur teratur penting untuk mengontrol sebagian efek radiasi penyebab serostomia. Bagi yang kekurangan gula, mengunyah permen karet dan permen asam dapat menolong. Pada beberapa pasien, pilocarpine hydrochloride merupakan jalan keluar. Tablet Salagen ${ }^{\circledR}$ efektif dalam merangsang produksi saliva (5 mg, 3 atau 4 kali sehari). Efek sampingnya adalah berkeringat dan rasa tidak nyaman pada perut. Perangsang saliva yang lain adalah cevimeline (Evoxac $\AA$ ), diberikan $30 \mathrm{mg}$ kapsul 3 kali sehari, telah membantu beberapa pasien serostomia. Obat ini kontraindikasi dengan pasien asma, ulkus gastrointestinal dan glaukoma. ${ }^{6}$

Solusi saliva buatan dan saliva yang digantikan dengan pelumas terbatas dalam membantu sebagian besar pasien serostomia. Walaupun beberapa laporan yang mendukung telah dipublikasikan Oral Balance ${ }^{\circledR}$ baik digunakan sebagai terapi. Pada beberapa pasien hipersalivasi (tipe sekresi mukosa yang melampaui batas), guaifenesin (Organidin NR®) dalam bentuk cair atau tablet mungkin dapat membantu sebagai agen mukolitik (200-400 mg, 3-4 kali sehari). ${ }^{6}$

\section{SIMPULAN}

Saliva mempunyai beberapa fungsi penting di dalam rongga mulut, diantaranya sebagai pelumas, aksi pembersihan, pelarutan, pengunyahan dan penelanan makanan, proses bicara, sistem buffer dan yang paling penting adalah fungsi sebagai pelindung gigi terhadap terjadinya karies

Terapi radiasi pada daerah kepala dan leher khususnya nasofaring mau tidak mau akan mengikutsertakan sebagian besar mukosa mulut dan kelenjar parotis. Akibatnya, dalam keadaan akut akan terjadi efek samping pada mukosa mulut berupa mukositis yang dirasakan oleh pasien sebagai nyeri saat menelan, mulut kering dan hilangnya cita rasa.

Akibat kelenjar parotis terkena radiasi dosis tinggi, akan terjadi disfungsi kelenjar berupa menurunnya aliran saliva yang akan diikuti dengan kekeringan pada mukosa mulut (serostomia). Bila saliva yang mempunyai fungsi antara lain mempertahankan $\mathrm{pH}$ mulut di angka netral dan ikut serta dalam membersihkan sisa sisa makanan ini berkurang, karies gigi akan lebih mudah terjadi.

\section{SARAN}

Untuk menghindari efek samping semaksimal mungkin maka sebelum dan selama pengobatan, bahkan setelah selesai terapi, pasien sebaiknya selalu diawasi oleh dokter. Perawatan sebelum radiasi adalah dengan membenahi gigi geligi, memberikan informasi kepada pasien mengenai metode pembersihan ruang mulut dan gigi secara benar.

\section{DAFTAR PUSTAKA}

1. Radiology Info. Head and neck cancer. Available from: http://www.radiologyinfo. org/en/info.cfm?pg=hdneck\&bhcp=1.

Accessed May 10, 2007. 
2. Otmani N. Oral and maxillofacial side effects of radiation therapy on children. J Can Dent Assoc [serial online] 2007 (4): [internet]. Available from: http://www.cdaadc.ca/jcda/vol-73/257.pdf. Accessed September 19, 2007.

3. Hasibuan S. Keluhan mulut kering ditinjau dari faktor penyebab, manifestasi dan penanggulangannya. Available from: http://library.usu.ac.id/modules.php?op=modl oad $\&$ name $=$ Downloads $\&$ file $=$ index $\&$ req=getit\&lid=334. Diakses: 5 Maret 2007.

4. Lawrence HP. Salivary markers of systemic disease: noninvasive diagnosis of disease and monitoring of general health. J Can Dent Assoc 2002; 68 (3):170-4..

5. White SC, Michael JP. Oral radiology principles and interpretation. $5^{\text {th }}$ Ed. Philadelphia: Mosby; 2000. p. 25-37.

6. Rosenbaum EH. Mucositis-oral problems and solution. Available from: http://www. cancersupportivecare.com/oral.html. Diakses: 13 Maret 2007.

7. Gupta A, Joel BE, Herve S. Hyposalivation in elderly patients. J Can Dent Assoc 2006; 72 (9): 841-6. 